\title{
Construction of Subtractive CDNA Library Using Magnetic Beads and PCR
}

\section{Anders Lönneborg, ${ }^{1}$ \\ Praveen Sharma, ${ }^{1}$ and Peter Stougaard ${ }^{2}$}

${ }^{1}$ Norwegian Forest Research Institute, Høgskoleveien $12, \mathrm{~N}-1432$ Ås, Norway; ${ }^{2}$ Biotechnological Institute, Anker Engelonds Vej 1, DK-2800 Lyngby, Denmark
Differentially expressed genes have been studied in many experimental systems. Such systems could encompass the analysis of differences between closely related species or varieties, ${ }^{(1)}$ genes expressed differentially in different tissues, ${ }^{(2)}$ and investigation of gene expression in relation to external stimuli (e.g., addition of hormones, drugs, pathogens, elevated temperature, or $\mathrm{pH}) .^{(3-6)}$ Cloning and characterization of genes that are differentially expressed has long been troublesome and laborious, as it is necessary to isolate large amounts of mRNA for the construction of a cDNA library, and traditionally, this library is screened with two probes specific for, for example, induced and noninduced genes. ${ }^{(7)}$ Alternatively, cDNA libraries can be screened with subtracted probes prepared from labeled cDNA corresponding to mRNA from treated cells subtracted with mRNA from untreated cells. ${ }^{(7)}$ Such an experiment requires large amounts of mRNA for cDNA library construction and for probe construction and is rather time consuming and laborious, as each protocol includes several steps.

Recent advances in molecular biology have provided powerful tools for construction of cDNA libraries and subtractive hybridization. PCR has proved to be a very efficient method for the amplification of DNA to be used in CDNA library construction, ${ }^{(3,8-10)}$ and the use of oligo(dT) coupled to magnetic beads has in several cases been shown to facilitate handling of small amounts of mRNA and cDNA. ${ }^{(8,11,12)}$ The advantage of using subtractive libraries is primarily that the size of the library can be reduced, as constitutively expressed housekeeping genes and repetitive sequences will have a very low representation in such libraries. However, induced genes or pseudogenes with homology to constitutively expressed genes are not represented in the subtracted libraries either. Also, induced genes with an additional low constitutive expression level may not be represented in the library. Other problems may arise from the use of PCR in library construction, as PCR preferentially amplifies short cDNA sequences or sequences without the potential of forming secondary structures. Thus, a cDNA library constructed by PCR may not represent the pool of mRNA molecules. However, in many cases the advantages of using PCR overshadow the disadvantages, as PCR allows the manipulation of very small amounts of cDNA.

We have combined these two powerful methods and have developed a strategy for the construction of cDNA libraries ${ }^{(6)}$ (Fig. 1). This method, which is described in detail below, was first used to construct a subtracted cDNA library enriched for cDNA clones unique to roots of Norway spruce infected with the fungal root pathogen Pythium dimorphum. ${ }^{(6)}$ The protocol has been used successfully later to construct a subtracted cDNA library from giant cells in tomato roots infected by a root-knot nematode. ${ }^{(13)}$ There is no reason to believe that this method should not work for organisms other than plants as well.

\section{Protocol 1: Isolation of RNA}

This protocol, described in Jacobsen et al., ${ }^{(11)}$ is an effective method to isolate mRNA directly from plant tissue without first having to isolate total RNA. If preferred, this method can easily be adjusted to isolate mRNA from total RNA.

1. Grind 1.75 gram of tissue, or $5 \times 10^{6}$ cells when starting from cultured cells, to be used for subtraction (driver) to a fine powder in liquid nitrogen in a mortar.

2. Grind 0.25 gram of tissue, or $0.7 \times 10^{6}$ cells when starting from cultured cells, to be subtracted (target) in the same way.

3. Homogenize the samples in a glass homogenizer with $1.2 \mathrm{ml}$ of lysis/ poly(A)-binding buffer. As an alternative, the samples can be transferred to another mortar and ground with lysis/poly(A)-binding buffer. 
4. Spin the samples for $30 \mathrm{sec}(10,000 \mathrm{~g})$ in a microcentrifuge.

5. Transfer the supernatant of both samples to new microcentrifuge tubes containing $2 \mathrm{mg}$ of oligo(dT) ${ }_{25}$ Dynabeads (Dynal) suspended in $100 \mu \mathrm{l}$ of lysis/poly(A)-binding buffer.

6. Incubate 4-5 min on ice to let the RNA anneal to the magnetic beads.

7. Place the tube in a rack with a magnet (i.e., Dynal MPC-E) at room temperature so that the magnetic beads are collected on the microcentrifuge tube wall. Depending on the viscosity, allow 2-5 min for the collection of magnetic beads.

8. Remove the supernatant while the beads are still attached to the tube wall.

9. Wash the magnetic beads three times at room temperature in $1 \mathrm{ml}$ of washing buffer. Depending on the tissue used, 2-4 $\mu \mathrm{g}$ of mRNA should be attached to the magnetic beads.

10. Add $30 \mu \mathrm{l}$ of distilled RNase-free water and incubate the tube with attached target mRNA at $65^{\circ} \mathrm{C}$ for $2 \mathrm{~min}$. Immediately place the tube in the magnetrack, allow $30 \mathrm{sec}$ for the collection of magnetic beads, and transfer the supernatant containing eluted target mRNA to a new tube. Driver DNA is used for first-strand cDNA synthesis directly on the Dynabeads.

The amount of RNA available varies depending on the material used. The average yield of RNA per gram of tissue is reported to be $8 \mathrm{mg}$ in liver, $1-1.5$ mg in muscle tissue, $0.5 \mathrm{mg}$ in pea seedlings, and $0.2 \mathrm{mg}$ in Arabidopsis plants. Because mRNA usually constitutes $1-5 \%$ of total RNA, the average yield of extractable mRNA per gram of tissue is $\sim 2-400 \mu \mathrm{g}$. Using the information from the supplier that $2 \mathrm{mg}$ of Dynabeads binds $4 \mu \mathrm{g}$ of mRNA, this protocol can be adjusted accordingly.

We prefer using Dynabeads instead of other magnetic particles because of their higher capacity to bind mRNA and their small and uniform size, which makes them easier to keep in suspension.

\section{FIRST-STRAND CDNA SYNTHESIS}

\section{Protocol 2: Alternative 1}

This method is described in the cDNA Synthesis System Plus kit (Amersham). The buffers and enzymes provided in this kit can be used in exchange for those listed here.

1. Wash the magnetic beads with bound driver mRNA twice in $1 \mathrm{ml}$ of $5 \times$ reverse transcriptase (RT) buffer at room temperature.

2 . Resuspend the beads in $5 \times$ RT buffer to a calculated concentration of $\sim 0.25 \mu \mathrm{g} / \mu \mathrm{l}$ of mRNA.

3. Add in listed order to a tube on ice:

Driver mRNA $(1 \mu \mathrm{g})$ in $5 \times$ RT buffer

Sodium pyrophosphate solution $(80 \mathrm{~mm})$

$4 \mu l$

Human placental ribonuclease inhibitor $(200 \mathrm{U} / \mu \mathrm{l})$

$1 \mu l$

dNTP mix

$1 \mu l$

$\mathrm{H}_{2} \mathrm{O}$

$1 \mu l$

$\frac{13 \mu l}{20 \mu l}$

4. Mix and spin in a microcentrifuge for a few seconds.

5. Add 20 units of AMV RT.

6. Incubate $42^{\circ} \mathrm{C}$ for at least $40 \mathrm{~min}$. Maintain the beads in suspension by incubating in a rotary hybridization oven.

7. Place the microcentrifuge tubes in a magnetrack, allow $30 \mathrm{sec}$ for the 


\section{Manual Supplement IIIIIII}

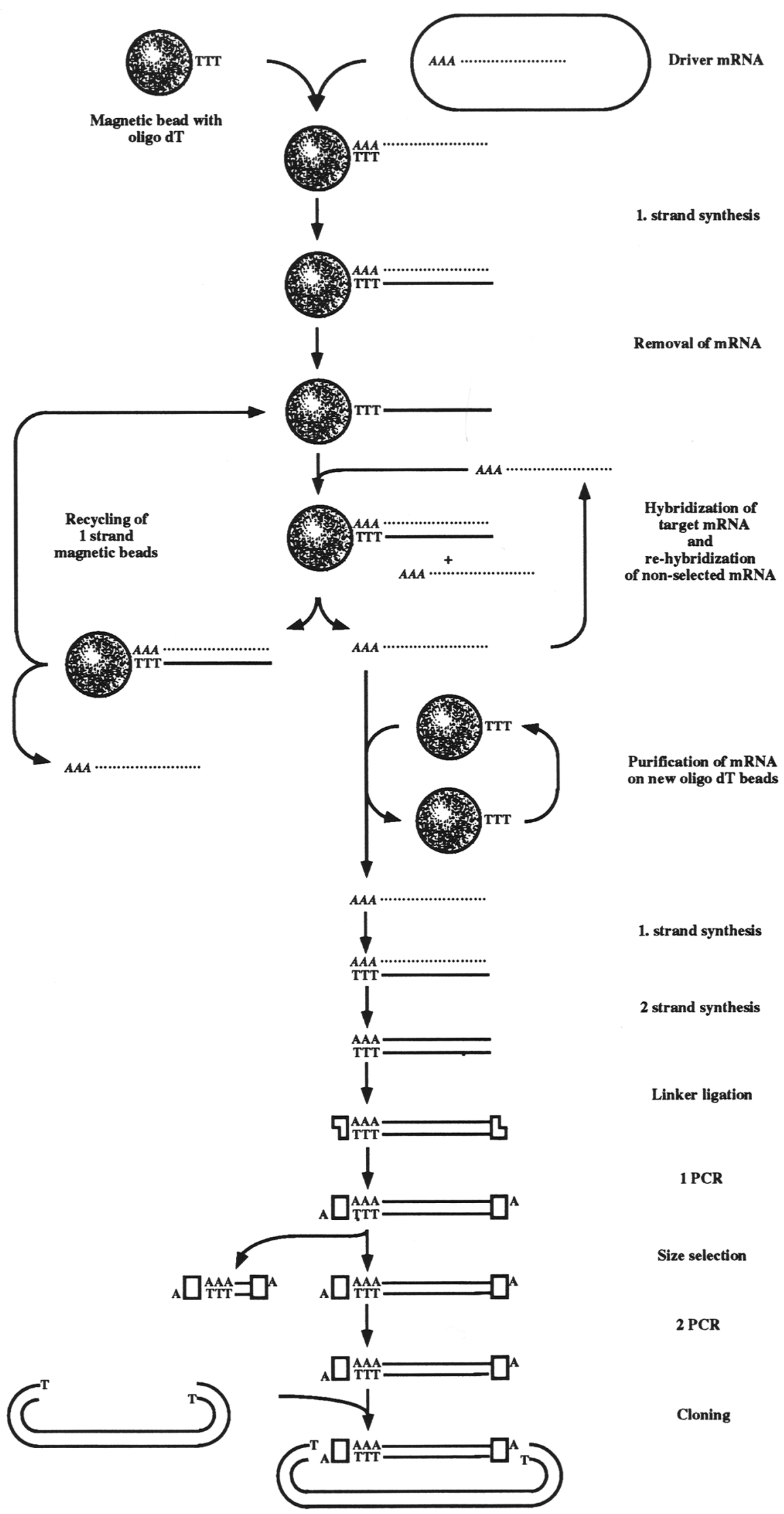

FIGURE 1 (See facing page for legend.) 
collection of magnetic beads containing RNA and first-strand CDNA, and discard the supernatant.

8. Wash the beads with $20 \mu \mathrm{l}$ of $2 \mathrm{~mm}$ EDTA at $95^{\circ} \mathrm{C}$ for $3 \mathrm{~min}$ in a water bath to remove the RNA. Immediately place the microcentrifuge tubes in a magnetrack and allow $30 \mathrm{sec}$ for the collection of beads. Discard the supernatant. Repeat the washing step once.

\section{Protocol 3: Alternative 2}

This alternative protocol is essentially as described by Raineri et al. ${ }^{(8)}$ The main difference from Alternative 1 is that Moloney murine leukemia virus (MoMLV) RT is used instead of AMV RT.

1. Wash the magnetic beads with bound driver mRNA twice in $5 \times \mathrm{RT}$ buffer at room temperature.

2 . Resuspend the beads in $5 \times \mathrm{RT}$ buffer to a calculated concentration of $\sim 0.25 \mu \mathrm{g} / \mu \mathrm{l}$ mRNA.

3. Add in listed order to a tube on ice:

Driver mRNA $(1 \mu \mathrm{g})$ in RT buffer

DTT $(0.1 \mathrm{M})$

Human placental ribonuclease inhibitor $(200 \mathrm{U} / \mu \mathrm{l})$ dNTP mix

$\mathrm{H}_{2} \mathrm{O}$
$4 \mu \mathrm{l}$

$2 \mu l$

$1 \mu l$

$2 \mu l$

$\frac{11 \mu l}{20 \mu l}$

4. Mix and spin in a microcentrifuge for a few seconds.

5. Add 25-50 units of MoMLV RT.

6. Incubate for $1 \mathrm{hr}$ at $42^{\circ} \mathrm{C}$. Maintain the beads in suspension by incubating in a rotary hybridization oven.

7. Wash twice with $2 \mathrm{mM}$ EDTA at $95^{\circ} \mathrm{C}$ for $3 \mathrm{~min}$ to remove the mRNA.

\section{Protocol 4: Subtractive Hybridization}

1. Capture the first-strand driver cDNA coupled to the magnetic beads with a magnet, discard the EDTA solution, and resuspend the beads in $90 \mu \mathrm{l}$ of hybridization buffer.

2. Add $15 \mu \mathrm{l}$ of the previously isolated target mRNA.

3. Overlay the hybridization mix with paraffin oil.

4. Denature the sample at $95^{\circ} \mathrm{C}$ for $3 \mathrm{~min}$.

5. Hybridize at $65^{\circ} \mathrm{C}$ for $24 \mathrm{hr}$ in a rotary hybridization oven to keep the beads suspended.

6. Capture the cDNA-containing beads with hybridized mRNA using a magnet.

7. Remove the paraffin oil with a pipette.

8. Collect the supernatant containing unhybridized mRNA, and transfer the beads to a fresh microcentrifuge tube.

9. Add $1 \mathrm{ml}$ of water and incubate at $95^{\circ} \mathrm{C}$. After $1 \mathrm{~min}$ of incubation, capture the beads with a magnet and discard the supernatant containing mRNA that hybridized to the cDNA coupled to magnetic beads. Repeat the elution once.

10. Wash the recycled beads twice in $1 \mathrm{ml}$ of washing buffer at room temperature.

11. Add the collected supernatant from step 8 to the recycled cDNA-containing magnetic beads and repeat the hybridization three times.

FIGURE 1 Outline of the protocol for substraction of mRNA and construction of a PCR-amplified cDNA library. Broken lines indicate mRNA; solid lines are DNA; and large shaded circles represent oligo(dT) magnetic beads. For further details see text. 
12. Unhybridized mRNA after the third hybridization is captured with 1 $\mathrm{mg}$ of fresh oligo(dT) ${ }_{25}$ Dynabeads in $50 \mu \mathrm{l}$ of lysis/poly(A)-binding buffer.

13. Elute the bound mRNA in $10 \mu$ l of water at $55^{\circ} \mathrm{C}$ for $5 \mathrm{~min}$.

14. Repeat step 13 and pool the supernatants.

At a temperature of $65^{\circ} \mathrm{C}$, hybridization between a poly(A) tail and the oligo(dT) on the beads does not occur. Thus, the risk of capturing driver mRNA for use in the next subtraction cycles is avoided.

The number of hybridization cycles necessary for subtractive hybridization is difficult to predict but may be determined empirically. Increasing the number of cycles will enrich for unique target transcripts. cDNA corresponding to transcripts present in high amounts in the target mRNA population and, at the same time, also present in smaller amounts as driver mRNA will be underrepresented or even absent in the subtracted cDNA library. The efficiency of the subtraction after each cycle may be monitored using a hybridization probe recognizing transcripts present in the pools of driver and of target mRNA. If subtraction is effective the probe should not give any detectable signal after three to four cycles.

The recycled first-strand driver cDNA can also be used for purposes other than subtractive hybridization. For example, it can be labeled and used later as a hybridization probe in the characterization of the library and of isolated clones.

\section{Protocol 5: Second-strand Synthesis}

This method is essentially according to the protocol for cDNA Synthesis System Plus provided by Amersham. The buffers and enzymes provided in their kit can be used in place of those listed here. The first strand is synthesized as described previously, but only to step 6. Do not add any EDTA. Then proceed as follows:

1. Mix in a microcentrifuge tube on ice:

First-strand cDNA reaction mix Second-strand buffer, $5 \times$ Escherichia coli ribonuclease $\mathrm{H}$ E. coli DNA polymerase I $\mathrm{H}_{2} \mathrm{O}$

$$
\begin{aligned}
& 20 \mu \mathrm{l} \\
& 37.5 \mu \mathrm{l} \\
& 0.8 \text { units } \\
& 23 \text { units } \\
& \times \mu l \\
& \hline 100 \mu \mathrm{l}
\end{aligned}
$$

2. Mix gently and incubate at $12^{\circ} \mathrm{C}$ for $60 \mathrm{~min}$.

3. Incubate at $22^{\circ} \mathrm{C}$ for $60 \mathrm{~min}$.

4. Incubate at $70^{\circ} \mathrm{C}$ for $10 \mathrm{~min}$.

5. Spin in a microcentrifuge for a few seconds.

6. Place on ice. Add 2.0 units of T4 DNA polymerase per microgram of original mRNA template.

7. Mix and incubate at $37^{\circ} \mathrm{C}$ for $10 \mathrm{~min}$.

8. Add $4 \mu$ l of $0.25 \mathrm{M}$ EDTA at $\mathrm{pH} 8.0$ per $100 \mu$ l of final reaction mix to stop the reaction.

\section{Protocol 6: Adapter Ligation}

For adapter ligation, ${ }^{(10)}$ the following oligonucleotides work well, but other oligonucleotides with other restriction sites may be preferred when cloning in other vectors. For example, introducing a site for a rare cutter like NotI would reduce the risk of internal digests when digestion is needed or preferred for cloning.

Oligonucleotide 1 (29-mer); 5'-ATG CTT AGG AAT TCC GAT TTA GCC TCA TA-3' (EcoRI). 
Oligonucleotide 2 (12-mer); 5'-TAT GAG GCT AAA-3'.

1. Dissolve $100 \mu \mathrm{g}$ of oligonucleotide 1 , and $40 \mu \mathrm{g}$ of oligonucleotide 2 in $50 \mu \mathrm{l}$ of STE.

2. Heat the oligonucleotide mixture at $70^{\circ} \mathrm{C}$ for $2 \mathrm{~min}$. Turn off the water bath and allow to cool down to $30^{\circ} \mathrm{C}$.

3. Add the following to a microcentrifuge tube and mix:

\begin{tabular}{lc} 
cDNA & $10 \mu \mathrm{l}$ \\
Annealed oligonucleotides & $2.5 \mu \mathrm{l}$ \\
ATP, $10 \mathrm{~mm}$ & $2 \mu \mathrm{l}$ \\
Ligase buffer, $10 \times$ & $2 \mu \mathrm{l}$ \\
$\mathrm{H}_{2} \mathrm{O}$ & $2.5 \mu \mathrm{l}$ \\
T4 DNA ligase $(2.5 \mathrm{U} / \mathrm{ml})$ & $1 \mu \mathrm{l}$ \\
\hline
\end{tabular}

4. Incubate at $16^{\circ} \mathrm{C}$ overnight.

5. Extract with phenol/chloroform.

6. Remove excess adaptors on a spin column, e.g., Miniprep Spun Columns (Pharmacia). Adjust the sample volume to $100 \mu$ l with STE.

7. Apply the sample on an STE-equilibrated column.

8. Spin the column.

9. Precipitate the sample with ethanol.

10. Resuspend the pellet in $50 \mu \mathrm{l}$ of $\mathrm{H}_{2} \mathrm{O}$.

\section{Protocol 7: PCR Amplification of CDNA}

For PCR amplification of cDNA, see Ref. 10.

1. Add to a microcentrifuge tube and mix:

$\begin{array}{lr}\text { PCR buffer, } 10 \times & 5.0 \mu \mathrm{l} \\ \text { Oligonucleotide } 1,600 \mathrm{ng} & 6.0 \mu \mathrm{l} \\ \text { dNTP stock, } 10 \mathrm{mM} \text { each dNTP } & 1.0 \mu \mathrm{l} \\ \text { cDNA } & 5.0 \mu \mathrm{l} \\ \mathrm{H}_{2} \mathrm{O} & \frac{33.0 \mu \mathrm{l}}{50.0 \mu \mathrm{l}}\end{array}$

2. Apply a few drops of mineral oil on top of the PCR mix.

3. Boil sample for $10 \mathrm{~min}$.

4. Place the tube in a temperature cycler at $80^{\circ} \mathrm{C}$.

5. After a minute, add $1 \mu \mathrm{l}$ of Taq DNA polymerase (AmpliTaq) and return the sample immediately to the temperature cycler.

7. Run $10 \mu \mathrm{l}$ of the PCR mixture on a $1 \%$ low melting agarose (NuSieve) gel.

8. Cut away fragments smaller than $\sim 500 \mathrm{bp}$.

9. Run the gel in reverse orientation with the same voltage as in step 7 until the remaining fraction is well concentrated. This is achieved when the sample dye is close to the well.

10. Cut out the concentrated fraction from the gel and recover the cDNA in $20 \mu \mathrm{l}$ of $\mathrm{H}_{2} \mathrm{O}$. Alternatively, the gel piece containing the cDNA may be melted and an aliquot used directly in the next step.

11. Repeat the PCR amplification with $5 \mu$ l of the recovered cDNA fraction.

12. Run $5 \mu$ l of the sample to check the size distribution of amplified DNA by agarose gel electrophoresis ( $1 \%$ agarose).

13. Extract with phenol/chloroform to inactivate the Taq DNA polymerase.

14. Ethanol-precipitate and resuspend in $20 \mu \mathrm{l}$ of $\mathrm{H}_{2} \mathrm{O}$. 
The cDNA after the second PCR is not purified on an agarose gel, to save the adenosine overhang produced by the Taq DNA polymerase. If this overhang is lost it would severely affect the efficiency of ligation in the next step when the cDNAs are cloned into the PCR II vector (TA Cloning System, Invitrogen).

\section{Protocol 8: Cloning the cDNA into the Vector}

1. Add in a microcentrifuge tube and mix:

CDNA

PCR II vector

Ligase buffer, $10 \times$

ATP, $10 \mathrm{~mm}$

$\mathrm{H}_{2} \mathrm{O}$

T4 DNA ligase, $2.5 \mathrm{U} / \mathrm{ml}$

$$
\begin{array}{r}
x \mu l \\
y \mu l \\
1.0 \mu l \\
1.0 \mu \mathrm{l} \\
z \mu \mathrm{l} \\
0.5 \mu \mathrm{l} \\
\hline 10.0 \mu \mathrm{l}
\end{array}
$$

2. Incubate at $16^{\circ} \mathrm{C}$ overnight.

3. Heat at $75^{\circ} \mathrm{C}$ for $10 \mathrm{~min}$.

4. Dilute $2 \mu \mathrm{l}$ of ligation mixture with $10 \mu \mathrm{l}$ of water.

5. Transform competent $E$. coli with the diluted ligation mixture and plate the transformed $E$. coli at different dilutions to estimate the number of clones in the library.

The ratio between vector and $\mathrm{cDNA}$ ends should be $\sim 1$. However, as the concentration of cDNA ends may be difficult to calculate, it may be necessary to use different amounts of cDNA in the ligation.

The cDNA can also be digested with EcoRI utilizing the restriction site in the adaptor. In this way, other vectors (e.g., $\lambda$ vectors) can be used. However, we try to reduce the enzymatic manipulations to a minimum as they all will reduce the yield of the final product, the cDNA clones. Also, the risk of fragmenting of cDNAs because of internal EcoRI sites is reduced.

\section{TROUBLESHOOTING}

It is essential for all work in constructing a subtracted cDNA library to extract high-quality mRNA from the tissue of interest. The method described is very quick, which will minimize the risk of degradation. However, it is also of great importance to handle and store the tissue in an optimal way to avoid RNase activity. If the mRNA cannot be extracted at once after tissue sampling it should be frozen immediately in liquid nitrogen and stored at $-80^{\circ} \mathrm{C}$ until extraction. For the same reason, all buffers coming in contact with the RNA should be free of RNase activity.

To avoid unintended binding of target mRNA to free oligo(dT) sites on the magnetic beads during the subtractive hybridization, it is important to perform the hybridization at a stringent temperature. Stringent temperature also avoids nonhomologous hybridization. It has been reported that high temperatures $\left(65-68^{\circ} \mathrm{C}\right)$ may cause breaks and/or degradation of mRNA. ${ }^{(5)}$ The use of formamide in the hybridization solution avoids this problem and makes it possible to perform a high-stringency hybridization at $42-45^{\circ} \mathrm{C}^{(5)}$ The same workers also recommend the use of autoclaved mineral oil to avoid contaminating nuclease activities. ${ }^{(5)}$

We have utilized the adenosine overhang produced by Taq DNA polymerase in our cloning strategy. Using this overhang it is possible to clone the cDNAs directly into the vector without further modification of the ends with restriction enzymes. This has two advantages: (1) All extra manipulations will reduce the yield of cloned CDNA; and (2) the risk of degradation of the cDNA because of existing internal sites for the enzyme is avoided. However, the adenosine overhang is rather unstable and is easily lost when separating the 
cDNA in an agarose gel. Therefore, it is important to avoid such a separation after the last PCR amplification.

\section{CONCLUSION}

PCR and oligo(dT) magnetic beads have proved to be very powerful tools in the handling of small amounts of mRNA and DNA. Using magnetic beads and PCR we have constructed subtractive libraries enriched for differentially expressed genes from $250 \mathrm{mg}$ of tissue. After cDNA synthesis, the recycled firststrand cDNA coupled to magnetic beads can be used for another round of subtraction and for synthesis of the probes used in the screening of the libraries.

\section{BUFFERS}

\section{Lysis/Poly(A)-binding Buffer \\ $500 \mathrm{~mm} \mathrm{LiCl}$ \\ $100 \mathrm{~mm}$ Tris- $\mathrm{HCl}$ at $\mathrm{pH} 8.0$ \\ 10 mM EDTA \\ $1 \%$ lithium dodecylsulfate \\ $5 \mathrm{~mm}$ DTT}

\section{Washing Buffer}

$150 \mathrm{~mm} \mathrm{LiCl}$

$10 \mathrm{~mm}$ Tris- $\mathrm{HCl}$ at $\mathrm{pH} 8.0$

1 mM EDTA

$0.1 \%$ SDS

\section{dNTP Mix}

$7 \mathrm{mM}$ dATP

$7 \mathrm{mM} \mathrm{dCTP}$

$7 \mathrm{mM}$ dGTP

$7 \mathrm{mM}$ dTTP

\section{Reverse Transcriptase Buffer, $5 \times$}

$250 \mathrm{~mm}$ Tris- $\mathrm{HCl}$ at $\mathrm{pH} 8.3$

$375 \mathrm{~mm} \mathrm{KCl}$

$15 \mathrm{mM} \mathrm{MgCl}_{2}$

$50 \mathrm{~mm}$ DTT

Hybridization Buffer

$120 \mathrm{mM} \mathrm{NaP}_{\mathrm{i}}$ at $\mathrm{pH} 6.8$

$820 \mathrm{~mm} \mathrm{NaCl}$

$1 \mathrm{mM}$ EDTA

$0.1 \%$ SDS

\section{Second-strand Buffer, $5 \times$}

$100 \mathrm{~mm}$ Tris- $\mathrm{HCl}$ at $\mathrm{pH} 7.5$

$500 \mathrm{mM} \mathrm{KCl}$

$25 \mathrm{mM} \mathrm{MgCl}_{2}$

$0.25 \mathrm{mg} / \mathrm{ml}$ of BSA

$50 \mathrm{mM}\left(\mathrm{NH}_{4}\right)_{2} \mathrm{SO}_{4}$ 
STE

$100 \mathrm{~mm} \mathrm{NaCl}$

$10 \mathrm{~mm}$ Tris- $\mathrm{HCl}$ at $\mathrm{pH} 7.5$

0.1 mM EDTA

\section{PCR Buffer, 10x}

$500 \mathrm{~mm} \mathrm{KCl}$

$100 \mathrm{mM}$ Tris- $\mathrm{HCl}$ at $\mathrm{pH} 8.3$

$15 \mathrm{mM} \mathrm{MgCl}_{2}$

$0.1 \%(\mathrm{wt} / \mathrm{vol})$ gelatin

\section{Ligase Buffer, 10x}

$50 \mathrm{~mm}$ Tris- $\mathrm{HCl}$ at $\mathrm{pH} 7.8$

$10 \mathrm{mM} \mathrm{MgCl}_{2}$

$10 \mathrm{~mm}$ DTT

$25 \mu \mathrm{g} / \mathrm{ml}$ of BSA

\section{REFERENCES}

1. Darasse, A., A. Koutoujansky, and Y. Bertheau. 1994. Isolation by genomic subtraction of DNA probes specific for Erwinia carotovora subsp. atroseptica. Appl. Environ. Microbiol. 60: 298-306.

2. Maréchal, D., C. Forceille, D. Breyer, D. Delapierre, and A. Dresse. 1993. A subtractive hybridization method to isolate tissue-specific transcripts: Application to the selection of new brain-specific products. Anal. Biochem. 208: 330-333.

3. Hara, E., T. Kato, S. Nakada, S.Sekiya, and K. Oda. 1991. Subtractive cDNA cloning using oligo $(\mathrm{dT})_{30}$-latex and PCR: Isolation of cDNA clones specific to undifferentiated human embryonal carcinoma cells. Nucleic Acids Res. 19: 7097-7104.

4. Barilá, D., C. Murgia, F. Nobili, S. Gaetani, and G. Perozzi. 1994. Subtractive hybridization cloning of novel genes differentially expressed during intestinal development. Eur. J. Biochem. 223: 701-709.

5. Wu, G., S. Su, and R.C. Bird. 1994. Optimization of subtractive hybridization in construction of subtractive cDNA libraries. Genet. Anal. Tech. Appl. 11: 29-33.

6. Sharma, P., A. Lönneborg, and P. Stougaard. 1993. PCR-based construction of subtractive cDNA library using magnetic beads. BioTechniques 15: 610-611.

7. Sambrook, J., E.F. Fritsch, and T. Maniatis. 1989. Molecular cloning: A laboratory manual. Cold Spring Harbor Laboratory Press, Cold Spring Harbor, New York.

8. Raineri, I., C. Moroni, and H.P. Senn. 1991. Improved efficiency for single-sided PCR by creating a reusable pool of first-strand cDNA coupled to a solid phase. Nucleic Acids Res. 19: 4010 .

9. Houge, G. 1993. Simplified construction of a subtracted cDNA library using asymmetric PCR. PCR Methods Appl. 2: 204-209.

10. Jepson, I., J. Bray, G. Jenkins, W. Schuch, and K. Edwards. 1991. A rapid procedure for the construction of PCR cDNA libraries from small amounts of plant tissue. Plant Mol. Biol. Reporter 9: 131-138.

11. Jacobsen, K.S., E. Breivold, and E. Hornes. 1990. Purification of mRNA directly from crude plant tissues in 15 minutes using magnetic oligo dT microspheres. Nucleic Acids Res. 18: 3669 .

12. Schraml, P., R. Shipman, P. Stultz, and C.U. Ludwig. 1993. cDNA subtraction library construction using a magnet-assisted subtraction technique (MAST). Trends Genet. 9: 70-71.

13. Potter, R. (pers. comm.) Western Australia State Agriculture Biotechnology Centre, BES, Murdoch University, Perth, Western Australia. 


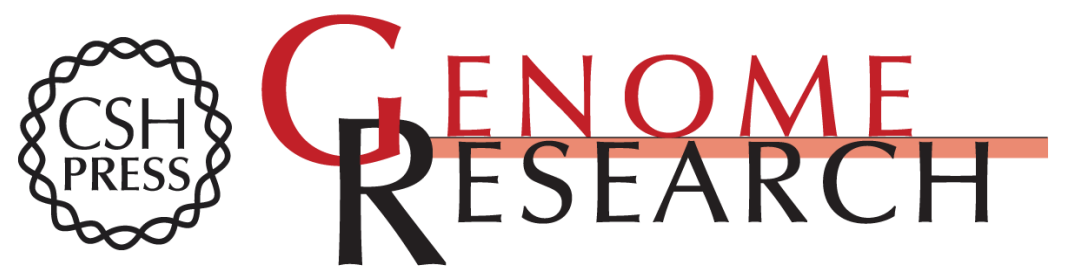

\section{Construction of subtractive cDNA library using magnetic beads and PCR.}

A Lönneborg, P Sharma and P Stougaard

Genome Res. 1995 4: S168-S176

References This article cites 11 articles, 1 of which can be accessed free at:

http://genome.cshlp.org/content/4/4/S168.full.html\#ref-list-1

License

Email Alerting Receive free email alerts when new articles cite this article - sign up in the box at the Service top right corner of the article or click here.

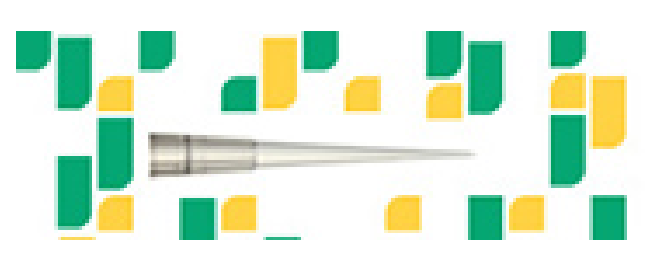

Focused on your science.

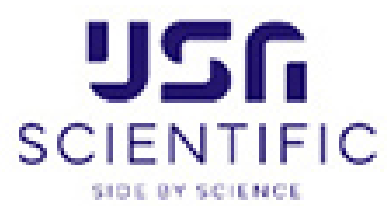

To subscribe to Genome Research go to:

https://genome.cshlp.org/subscriptions 